\title{
PIK3C2B Gene Amplification
}

National Cancer Institute

\section{Source}

National Cancer Institute. PIK3C2B Gene Amplification. NCI Thesaurus. Code C132896.

A molecular genetic abnormality indicating the presence of multiple copies of the PIK3C2B gene. 